\title{
Degradative Capacities and 16S rRNA-Targeted Whole-Cell Hybridization of Sulfate-Reducing Bacteria in an Anaerobic Enrichment Culture Utilizing Alkylbenzenes from Crude Oil
}

\author{
RALF RABUS,${ }^{1}$ MANABU FUKUI, ${ }^{2}$ HEINZ WILKES,${ }^{3}$ AND FRIEDRICH WIDDEL ${ }^{1 *}$ \\ Max-Planck-Institut für Marine Mikrobiologie, D-28359 Bremen, ${ }^{1}$ and Institut für Erdöl und \\ Organische Geochemie (ICG-4), Forschungszentrum Jülich GmbH, D-52428 Jülich, ${ }^{3}$ \\ Germany, and National Institute for Resources and Environment, \\ Tsukuba, Ibaraki 305, Japan ${ }^{2}$
}

Received 30 April 1996/Accepted 29 July 1996

\begin{abstract}
A mesophilic sulfate-reducing enrichment culture growing anaerobically on crude oil was used as a model system to study which nutritional types of sulfate-reducing bacteria may develop on original petroleum constituents in oil wells, tanks, and pipelines. Chemical analysis of oil hydrocarbons during growth revealed depletion of toluene and $o$-xylene within 1 month and of $m$-xylene, $o$-ethyltoluene, $m$-ethyltoluene, $m$-propyltoluene, and $m$-isopropyltoluene within approximately 2 months. In anaerobic counting series, the highest

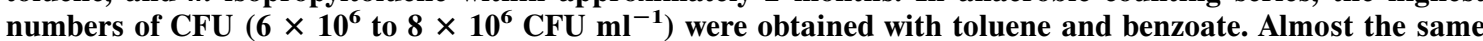
numbers were obtained with lactate, a substrate often used for detection of the vibrio-shaped, incompletely oxidizing Desulfovibrio sp. In the present study, however, lactate yielded mostly colonies of oval to rod-shaped, completely oxidizing, sulfate-reducing bacteria which were able to grow slowly on toluene or crude oil. Desulfovibrio species were detected only at low numbers $\left(3 \times 10^{5} \mathrm{CFU} \mathrm{ml}^{-1}\right)$. In agreement with this finding, a fluorescently labeled, 16S rRNA-targeted oligonucleotide probe described in the literature as specific for members of the Desulfovibrionaceae (suggested family) hybridized only with a small portion $(<5 \%)$ of the cells in the enrichment culture. These results are consistent with the observation that known Desulfovibrio species do not utilize aromatic hydrocarbons, the predominant substrates in the enrichment culture. All known sulfate-reducing bacteria which utilize aromatic compounds belong to a separate branch, the Desulfobacteriaceae (suggested family). Most members of this family are complete oxidizers. For specific hybridization with members of this branch, the probe had to be modified by a nucleotide exchange. Indeed, this modified probe hybridized with more than $95 \%$ of the cells in the enrichment culture. The results show that completely oxidizing, alkylbenzene-utilizing sulfate-reducing bacteria rather than Desulfovibrio species have to be considered in attempts to understand the microbiology of sulfide production in oil wells, tanks, and pipelines when no electron donors other than the indigenous oil constituents are available.
\end{abstract}

Production of sulfide in oil field waters, a process which is often referred to as souring, has frequently been of concern $(30,42)$. Hydrogen sulfide may lead to (i) poisoning upon inhalation, (ii) contamination of oil and gas and thus an increase in their sulfur content, (iii) corrosion of pipelines and other containments made of steel, and (iv) conversion of various iron minerals to ferrous sulfide; the latter may plug oilbearing strata and stabilize undesirable oil-water emulsions. At temperatures of less than approximately $100^{\circ} \mathrm{C}$, hydrogen sulfide obviously originates from bacterial sulfate reduction. High cell densities of sulfate-reducing bacteria have been repeatedly observed in production waters $(17,37,39,54)$, and numerous isolates from oil fields have been characterized elsewhere (1, $10,32,38,51,53,55,56)$. More recently, archaeal sulfate reducers were detected in and isolated from oil wells $(9,28$, 62). In addition, high fractionation of sulfur isotopes (with respect to parental sulfate) in preserved sulfide or in sulfur as an oxidation product of sulfide indicates that extensive bacterial sulfate reduction occurred in certain oil reservoirs $(40,60)$. During exploitation of oil fields, bacterial sulfate reduction is

\footnotetext{
* Corresponding author. Mailing address: Max-Planck-Institut für Marine Mikrobiologie, Celsiusstr. 1, D-28359 Bremen, Germany. Phone: 49-421-2028-702. Fax: 49-421-2028-790.
}

stimulated by injection of seawater $(30,42,53)$, which contains as much as $28 \mathrm{mM}$ sulfate. In reservoirs with temperatures of higher than approximately $100^{\circ} \mathrm{C}$, sulfide may be of purely chemical origin (43).

Development of controlling measures against microbial sulfate reduction in oil fields requires knowledge of the involved sulfate-reducing bacteria and their in situ growth substrates. In accordance with the nutritional capacities of sulfate reducers isolated from oil fields, various compounds have been discussed to serve as electron donors for sulfate reduction. These include (i) hydrogen from geothermal processes (62), from corroding or cathodically protected iron $(27,71)$, and from anaerobic degradation of compounds added or formed during operation $(17,39)$; (ii) fatty acids from ancient maturation processes $(8,35)$ and in situ hydrous pyrolysis (14); (iii) polar organic by-products formed by aerobic bacteria during growth on hydrocarbons $(12,39)$; and (iv) hydrocarbons as the major oil constituents $(1,58)$.

In addition to classical counting and isolation techniques, immunological methods as well as analysis and hybridization of nucleic acids may provide information about the types of sulfate-reducing bacteria that occur in stratal water and production waters of oil fields. Staining of cells in production waters with fluorescently labeled antibodies revealed the presence 
of thermophilic sulfate reducers of the genera Archaeoglobus and Thermodesulforhabdus (41). Hybridization of labeled total DNA from oil field samples against that from a set of isolates (reverse sample genome probing) revealed the presence of Desulfovibrio species and unidentified species of sulfate-reducing bacteria (67-69). Furthermore, fragments of genes coding for hydrogenases were used for identification of Desulfovibrio species among oil field isolates (66). The most frequently applied methods involving nucleic acids for differentiation of sulfate-reducing bacteria in heterogeneous cultures and environmental samples are based on rRNA sequences. For instance, the specificities of probes designed for various groups of sulfate-reducing bacteria of the suggested families Desulfovibrionaceae and Desulfobacteriaceae $(20,72)$ were demonstrated by hybridization with rRNA extracted from pure cultures and from sediment samples (21). One of these probes, which was termed 804, hybridized with rRNA from five genera of the Desulfobacteriaceae, including Desulfobacter and Desulfobacterium (21). Analysis of 16S rRNA genes amplified from DNA that had been extracted from oil field production waters indicated the presence of various genera of the Desulfovibrionaceae and Desulfobacteriaceae (65). Nucleic acid probes have also been used to hybridize $16 \mathrm{~S}$ rRNA in whole cells of sulfate-reducing bacteria. A fluorescently labeled probe termed SRB385 (3) allowed whole-cell detection of Desulfovibrio species in defined mixtures of eubacteria (3) and in biofilms (50). Cells of Desulfobacter species yielded a weak hybridization signal with this probe but gave a strong signal with another probe specifically designed for this genus $(3,50)$. In contrast to methods involving extracted nucleic acids, whole-cell hybridization has, to our knowledge, not been applied thus far to identify sulfate-reducing bacteria directly in samples from oil production waters.

In the present study, we used a previously established sulfate-reducing enrichment culture on crude oil (58) as a model system of bacterial habitats in which crude oil is the only potential source of organic substrates. This enrichment culture was recently shown to deplete crude oil of toluene, $o$-xylene, $m$-xylene, $o$-ethyltoluene, and $m$-ethyltoluene (58). In the present investigation, the enrichment culture is studied in more detail. (i) Consumption of particular alkylbenzenes is monitored over time to reveal possible substrate preferences. (ii) The major nutritional types of sulfate-reducing bacteria in the enrichment culture and their affiliation with known genealogic groups are examined by using classical counting techniques and $16 \mathrm{~S}$ rRNA-targeted whole-cell hybridization, respectively. The results suggest that the enrichment culture on crude oil is dominated by sulfate-reducing bacteria belonging to the suggested family of the Desulfobacteriaceae; these mainly completely oxidizing, sulfate-reducing bacteria (72) have only rarely been considered thus far in microbiological investigations in oil fields.

\section{MATERIALS AND METHODS}

Sources of organisms. The mesophilic enrichment culture of sulfate-reducing bacteria growing with crude oil as the only source of organic substrates originated from the water phase of a North Sea oil tank, Wilhelmshaven, Germany (58). Further enrichment cultures were obtained from sulfide-rich sediments of the Guaymas Basin, Gulf of California, Mexico (58), and a small North Sea harbor near Wilhelmshaven, Germany. Pure cultures of sulfate-reducing and other bacteria used for whole-cell hybridization were obtained from the Deutsche Sammlung von Mikroorganismen und Zellkulturen (DSM), Braunschweig, Germany, and the American Type Culture Collection, Rockville, Md.

Media and conditions of cultivation. The enrichment culture was grown in defined, bicarbonate-buffered, sulfide-reduced mineral medium, essentially having the same salt composition as natural seawater (72), under a head space of $\mathrm{N}_{2}-\mathrm{CO}_{2}(90: 10$ [vol/vol]). Flat bottles $(500 \mathrm{ml})$ with $400 \mathrm{ml}$ of medium and $12 \mathrm{ml}$ of crude oil were incubated horizontally to maximize the contact area between oil and medium and in this way facilitate substrate diffusion into the medium. The orifice sealed with a black rubber stopper was kept below the surface level of the medium to avoid adsorption of oil by the rubber $(1,46,48)$. Anoxic crude oil was prepared and stored in a special flask provided with a side arm for gas supply of $\mathrm{N}_{2}$ and an orifice sealed with Teflon-coated rubber (48). North Sea crude oil was kindly provided by J. Fischer, Wilhelmshaven, Germany.

Pure cultures of gram-negative sulfate-reducing bacteria $(46,72)$, Desulfuromonas acetoxidans (73), and Pelobacter acetylenicus (59) were grown in anoxic, bicarbonate-buffered, sulfide-reduced medium as described previously; according to the strain-specific salt requirements, either freshwater or saltwater medium as given in the corresponding literature was used. Desulfotomaculum ori entis was grown with thioglycolate and ascorbate as reductants instead of sulfide (72). Defined organic substrates were as suggested in the references; $D$. orientis was grown with lactate. Rhodospirillum rubrum was grown in reductant-free medium with exclusion of oxygen on succinate and yeast extract (18). Beggiatoa alba was cultivated aerobically in liquid medium with acetate and yeast extract instead of nutrient broth (18). All other bacteria, Halobacterium halobium and Saccharomyces cerevisiae, were grown aerobically on agar plates with complex organic substrates as described elsewhere $(6,18)$.

For determination of cell numbers, a sample from the enrichment culture was consecutively diluted in steps of 1:10 with liquid anoxic medium under $\mathrm{N}_{2}-\mathrm{CO}_{2}$ $(90: 10[\mathrm{vol} / \mathrm{vol}])$ in butyl-rubber-sealed tubes $(160 \mathrm{by} 16 \mathrm{~mm})$; transfers were made with $\mathrm{N}_{2}$-flushed syringes. From each dilution step, $0.5 \mathrm{ml}$ was then transferred to tubes containing approximately $10 \mathrm{ml}$ of medium with molten agar, as used for the isolation of sulfate-reducing bacteria (72). Benzoate, cyclohexanecarboxylate, or caprylate (sodium salts) was added to the molten agar at final concentrations of $2 \mathrm{mM}$; acetate and lactate were added at final concentrations of $10 \mathrm{mM}$. The less-water-soluble substrates toluene $(2 \%$ [vol/vol] in heptamethylnonane) and crude oil (undiluted) were added as a surface layer on top of the solidified agar (46), which in this case did not contain other organic substrates. The aromatic hydrocarbons were supplied to the cells in the agar by diffusion. The tubes were anoxically sealed under an atmosphere of $\mathrm{N}_{2}-\mathrm{CO}_{2}$ (90:10 [vol/vol]) and were incubated at $28^{\circ} \mathrm{C}$

Colonies for microscopic examination and further purification in subsequent agar dilutions were picked by means of finely drawn Pasteur pipettes (72).

For maintenance, the enrichment culture was incubated at $28^{\circ} \mathrm{C}$ for 6 weeks and then stored at $4^{\circ} \mathrm{C}$ for no longer than 8 weeks before subcultivation. No organic substrate other than crude oil was used for maintenance.

Chemical analyses. The amount of sulfide was determined by the methylene blue formation reaction in a colorimetric microassay as previously described (1)

Acetate and lactate were quantified by high-performance liquid chromatography on an ion exclusion column (300 by $7.8 \mathrm{~mm}$; type WA1; Sarasep, Santa Clara, Calif.). The eluent was $0.05 \mathrm{mM} \mathrm{H}_{2} \mathrm{SO}_{4}$. The temperature of the column was $70^{\circ} \mathrm{C}$, and the flow rate was $0.8 \mathrm{ml} / \mathrm{min}$. The amounts of lactate (retention time, $6.7 \mathrm{~min}$ ) and acetate (retention time, $9.7 \mathrm{~min}$ ) were determined with a conductivity detector. The detection limit was $10 \mu \mathrm{M}$

For oil analysis, samples were withdrawn from the oil phase of the enrichmen culture through the stoppered orifice by means of an $\mathrm{N}_{2}$-flushed syringe with a long $(60-\mathrm{mm})$ needle. The oil samples were fractionated by medium-pressure liquid chromatography (49), and the aromatic hydrocarbon fraction was analyzed by gas chromatography as described elsewhere (58). In addition, for the separation of $m$-xylene and $p$-xylene, the aromatic fraction was analyzed on an FSFFAP-CB-fused silica capillary column $(50 \mathrm{~m}$; inner diameter, $0.2 \mathrm{~mm}$; film thickness, $0.22 \mu \mathrm{m}$; Chromatographie Service, Langerwehe, Germany) with a type 3700 gas chromatograph (Varian, Darmstadt, Germany). The temperature program was run from $70^{\circ} \mathrm{C}$ (5-min isotherm) to $200^{\circ} \mathrm{C}$, at $3^{\circ} \mathrm{C} / \mathrm{min}$. The identification of $m$-propyltoluene was based on mass spectrometric data and comparison of relative gas chromatographic retention times with previously reported data (29). All other alkylbenzenes were identified by comparison of their gas chromatographic and mass spectrometric behavior with that of the authentic standards. Alkylbenzenes were quantified by determining their peak areas relative to that of naphthalene. Naphthalene yielded a prominent peak and belonged to those aromatic hydrocarbons which always exhibited the same ratio of peak areas before and after growth. Hence, naphthalene was considered an oil constituent that was not consumed under the given conditions (48).

The presence of desulfoviridin was tested by alkaline cell lysis under UV light (45)

Probing of whole cells. Oligodeoxynucleotide probes were synthesized by $\mathrm{Bi}$ ometra (Göttingen, Germany) with a DNA synthesizer (Applied Biosystems, Weiterstadt, Germany). The sequence of the previously described probe, SRB385 (3), was 5'-CGGCGTCGCTGCGTCAGG-3' (complementary to $16 \mathrm{~S}$ rRNA positions 402 to 385 [Escherichia coli numbering]). The sequence of the modified probe, termed SRB385Db, was 5'-CGGCGTTGCTGCGTCAGG-3' (complementary to the same positions as those of probe SRB385). Control assays were carried out with a universal probe, EUB338, which detected all eubacteria (3), as well as with a nonsense probe, ANT. Probe EUB338 had the sequence 5'-GCTGCCTCCCGTAGGAGT-3' (complementary to positions 355 to 338 [E coli numbering]). The nonsense probe had the antisense sequence of probe SRB385. Probe 804, which had been applied to extracted rRNA (21), had the sequence 5'-CAACGTTTACTGCGTGGA-3' (complementary to positions 804 to 821 [E. coli numbering]). All probes were labeled with fluorescein-5-isothiocyanate or tetramethylrhodamine-isocyanate. 
The culture fluid was withdrawn from the pressurized $(20 \mathrm{kPa})$, inverted bottles through the stoppers with a hypodermic needle. By this procedure, a transfer of oil and its interference with the staining procedure were avoided. The presently studied enrichment culture utilizing aromatic hydrocarbons grew homogeneously in the aqueous phase, and cells adhering to the oil phase were not detectable. Hence, the sample could be regarded as a representative cross section of the enrichment culture. The cells were washed with mineral medium and concentrated to an optical density at $660 \mathrm{~nm}$ of between 3 and 5. Cells from pure cultures for comparative hybridization experiments were washed in the respective media and concentrated in the same way.

The fixation and hybridization procedure was modified from that described by Amann et al. (4). For fixation, 1 volume of concentrated cell suspension was mixed with 3 volumes of $4 \%$ (wt/vol) paraformaldehyde in phosphate-buffered saline (PBS), and the mixture was incubated at $4^{\circ} \mathrm{C}$ for $5 \mathrm{~h}$. PBS contained $20 \mathrm{~g}$ of $\mathrm{NaCl}$ and $3.0 \mathrm{~g}$ of $\mathrm{MgCl}_{2} \cdot 6 \mathrm{H}_{2} \mathrm{O}$ (for marine bacteria) or $8.5 \mathrm{~g}$ of $\mathrm{NaCl}$ (for freshwater bacteria) per liter of $10 \mathrm{mM}$ sodium phosphate buffer ( $\mathrm{pH}$ 7.2). The cells were washed once with PBS to remove free paraformaldehyde, resuspended in PBS to yield a bacterial density of approximately $10^{9}$ cells per ml, mixed with the same volume of absolute cold ethanol, and stored at $-20^{\circ} \mathrm{C}$ for less than 4 weeks until hybridization. Hybridization was carried out on Teflon-covered slides with 10 glass surface windows (Cel-Line Associate, Newfield, N.J.) which were coated with gelatin $\left[0.1 \%\right.$ gelatin, $0.01 \% \mathrm{KCr}\left(\mathrm{SO}_{4}\right)_{2} \cdot 12 \mathrm{H}_{2} \mathrm{O}$, in $\mathrm{H}_{2} \mathrm{O}$; air dried on the slide]. Aliquots of the fixed cell suspensions ( 2 to $5 \mu \mathrm{l}$ ) were spread on each of the gelatin-coated windows and air dried. The cells were then dehydrated by subsequent incubation in 50,75, and $100 \%$ ethanol for 3 min (each step) at room temperature and were air dried. Each window was covered with $8 \mu$ l of hybridization buffer $(1.8 \mathrm{mM} \mathrm{NaCl}, 0.2 \mathrm{M}$ Tris- $\mathrm{HCl}$ [pH 7.2], $0.2 \%$ [wt/vol] sodium dodecyl sulfate, $30 \%$ [vol/vol] formamide) and $1 \mu \mathrm{l}$ of oligonucleotide probe $(25 \mathrm{ng})$. The compromise between signal intensity and stringency of hybridization was found to be optimal at a formamide concentration of $30 \%$ ( $\mathrm{vol} / \mathrm{vol}$ ) in the hybridization buffer (formamide concentrations tested, 0, 10, 20, $25,30,40,50$, and $60 \%$ [vol/vol] $)$. The slides were incubated for 2 to $5 \mathrm{~h}$ at $37^{\circ} \mathrm{C}$ in petri dishes which were sealed with Parafilm. To avoid drying of the sample, the petri dishes also contained a tissue soaked with hybridization buffer. Thereafter, the slides were incubated for $20 \mathrm{~min}$ in hybridization buffer at $37^{\circ} \mathrm{C}$ and then rinsed with distilled water to remove excess probe and salts. The slides were air dried in the dark. To prevent bleaching, 1 droplet of Citifluor (Citifluor, London, United Kingdom) was added to each window. The slides were sealed with a coverslip.

The hybridization result was examined with a fluorescence microscope (Axioplan; Zeiss, Oberkochen, Germany) equipped with a Peltier-cooled slow-scan charge-coupled device camera (Photometrics, Tucson, Ariz.) and a data system as previously described (50). The excitation wavelengths for the fluorescein-5isothiocyanate- and the rhodamine-labeled probes were 489 and $541 \mathrm{~nm}$, respectively; the emission wavelengths were 514 and $572 \mathrm{~nm}$, respectively.

The fluorescence intensities of cells hybridized with labeled oligonucleotide probes were accurately measured as pixel intensities with a confocal laser scanning microscope (type LSM410; Zeiss) as described elsewhere $(7,26)$. The mean pixel intensity of single cells on an individual image was calculated with the software provided by Zeiss.

\section{RESULTS}

Enrichment of sulfate-reducing bacteria on crude oil. Enrichment studies with saline inocula (10\% [vol/vol]) and crude oil were carried out to investigate if sulfate-reducing bacteria can in principle develop with oil constituents as sole electron donors and organic carbon sources. Mesophilic $\left(28^{\circ} \mathrm{C}\right)$ sulfideproducing $(\geq 10 \mathrm{mM}$ ) enrichment cultures on crude oil were obtained from every sample examined (North Sea oil tank, Guaymas Basin sediment, and coastal marine mud) within less than 8 weeks. A thermophilic $\left(60^{\circ} \mathrm{C}\right)$ enrichment culture was obtained from Guaymas Basin sediment (58), but not from the other samples. Inoculated control media without oil did not produce sulfide from sulfate. With respect to the aspect of bacterial substrate utilization, such enrichment cultures may be regarded as model systems of anoxic oil-bearing strata, oil wells, pipelines, and tanks in which oil is the only potential source of organic substrates for sulfate-reducing bacteria. So far, none of the enrichment cultures with crude oil has been examined with respect to its whole bacterial composition; only one strain of a new thermophilic alkane-utilizing, sulfate-reducing eubacterium from Guaymas Basin sediment has been briefly characterized (58). In the mesophilic enrichment culture from the oil tank, bacteria grew homogeneously distributed in the aqueous phase (optical density at $660 \mathrm{~nm}, 0.15$ ) and

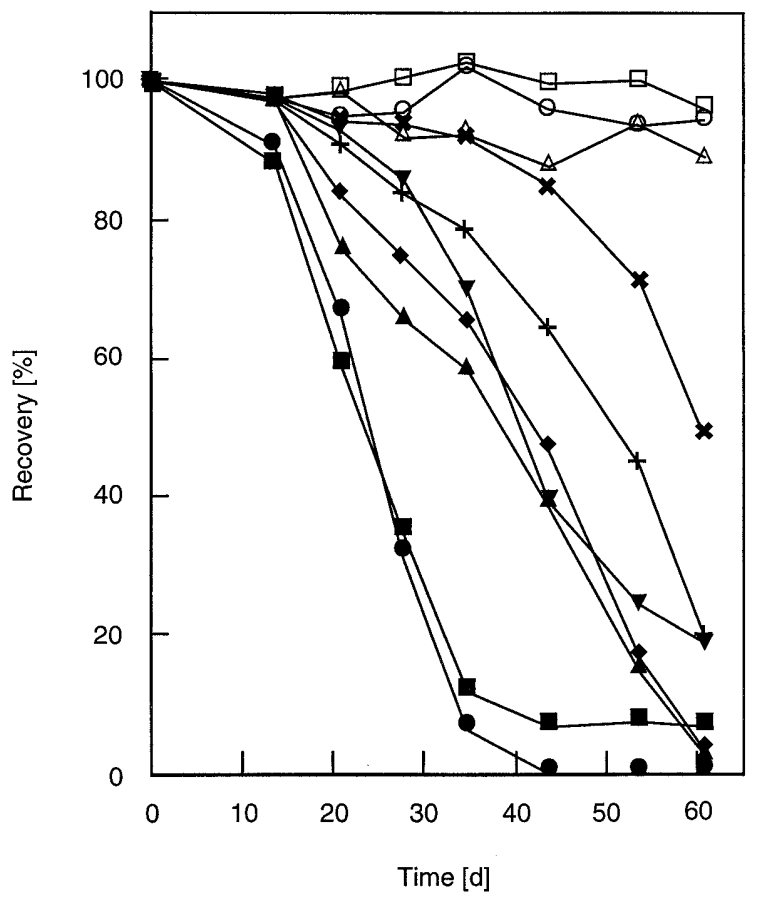

FIG. 1. Consumption of alkylbenzenes over time (d, days) in the oil-utilizing anaerobic enrichment culture. The consumption of alkylbenzenes at the given time points was calculated relative to their initial concentrations in the crude oil (recovery). Symbols for alkylbenzenes: $\mathbf{\square}$, toluene; $\boldsymbol{\bullet}, o$-xylene; $\boldsymbol{\Delta}, m$-xylene; $\boldsymbol{\nabla}$, $o$-ethyltoluene; $\bullet, m$-ethyltoluene;,$+ m$-propyltoluene; $\boldsymbol{x}, m$-isopropyltoluene; $\square$, ethylbenzene; $\bigcirc, p$-xylene; and $\triangle, p$-ethyltoluene.

did not adhere to or emulsify the oil. Homogeneous growth in this culture was consistent with the observation that the somewhat water-soluble alkylbenzenes rather than the insoluble alkanes were utilized from the crude oil (58). Such homogeneous growth facilitates attempts to obtain a representative cross section of the bacterial population via samples from the aqueous phase. Hence, the enrichment culture from the oil tank appeared particularly suitable for application for the first time of both classical cell counting and molecular probing of whole cells in the analysis of bacterial populations growing on crude oil.

Selective utilization of alkylbenzenes from crude oil. The previous analysis of oil from the enrichment culture was carried out after the third transfer and revealed a sulfate-dependent consumption of toluene, $o$-xylene, $m$-xylene, $o$-ethyltoluene, and $m$-ethyltoluene (58). Possible preferences for alkylbenzenes during growth could not be recognized thus far because the oil in the initial study was analyzed only at the end of growth. Therefore, the time course of the consumption of individual alkylbenzenes from the oil was monitored in the present study (Fig. 1); at this state, the enrichment culture had been transferred eight times. Analysis of oil samples taken at intervals of 8 to 9 days revealed that toluene and $o$-xylene were consumed most rapidly. In comparison to the culture after the earlier transfers (58), the present subculture used not only $\mathrm{C}_{1}$ to $\mathrm{C}_{3}$-alkylbenzenes (toluene, xylenes, and ethyltoluenes) but also $\mathrm{C}_{4}$-alkylbenzenes ( $m$-propyltoluene and $m$-isopropyltoluene [ $m$-cymene]). In agreement with former observations (58), no utilization of ethylbenzene, $p$-xylene, or $p$-ethyltoluene was detected.

Growth of the enrichment culture on crude oil was accelerated by incubation on a rotary shaker. Permanent shaking 
shortened the incubation time required for full growth from 6 to 3 weeks (inoculum size, $5 \%$ [vol/vol]). This indicated that growth in the nonagitated culture was probably limited by the rate of substrate diffusion from the oil into the medium.

Subcultivation on individual aromatic hydrocarbons. Growth of the enrichment culture in subcultures with individual alkylbenzenes (each $2 \%$ [vol/vol] in heptamethylnonane as carrier phase [46]) confirmed the degradative capacities observed in the presence of crude oil. Toluene, $o$-xylene, and $m$-xylene yielded significant growth (optical density at $660 \mathrm{~nm}, 0.2$ ) and net sulfide productions of 14,13 , and $7 \mathrm{mM}$, respectively, within 5 weeks (inoculum size, $5 \%$ [vol/vol]; incubation without shaking). $o$-Ethyltoluene and $m$-ethyltoluene were poorer growth substrates, yielding low cell densities (optical density at $660 \mathrm{~nm}, \leq 0.1$ ) and net sulfide productions of 4 and $2 \mathrm{mM}$, respectively, within 8 weeks. In contrast, neither growth nor sulfide formation occurred with ethylbenzene, $p$-xylene, or $p$ ethyltoluene.

Cell counting. The abundance of nutritional types of sulfatereducing bacteria in the enrichment culture was determined in counting series with fatty acids and toluene as potential electron donors in oil fields $(8,17,53,58)$, with benzoate as a suitable substrate of various alkylbenzene-degrading anaerobes $(11,46,47)$, and with crude oil. In counting series without added substrate, only small (diameter, $\leq 0.1 \mathrm{~mm}$ ), frayed white colonies appeared, which probably grew on organic trace constituents of the agar; the abundance of these colonies corresponded to $10^{5} \mathrm{CFU} / \mathrm{ml}$. With any organic substrate added, distinct ochre-to-yellowish-brown, compact colonies (diameter, $>0.1$ $\mathrm{mm}$ ) typical of sulfate-reducing bacteria (72) developed in addition. With substrates added as a surface layer (crude oil or toluene) to the agar tubes, the first three dilutions yielded pronounced zones of colony growth near the surface. At higher dilutions, colonies grew randomly distributed throughout the agar. The numbers of CFU obtained per $\mathrm{ml}$ of the enrichment culture were between approximately $6 \times 10^{6}$ and $8 \times 10^{6}$ with either crude oil, toluene, or benzoate and $2 \times 10^{6}$ with either acetate, caprylate, or cyclohexanecarboxylate. When well-separated pigmented colonies (20 colonies from agar tubes with oil, toluene, or benzoate) were transferred to liquid media with the corresponding substrate, growth with concomitant sulfide production occurred.

Since lactate is often employed for routine counting of sulfate-reducing bacteria $(42,45)$, cell counts were also determined with this substrate, and the development of colonies was examined in more detail. Lactate has been proven to be an excellent substrate for all Desulfovibrio species (45); however, it is also utilized by species of several other genera of sulfatereducing bacteria (72). Indeed, at least two distinct populations of colonies developed with lactate. During the first week, relatively few big (diameter, approximately $1 \mathrm{~mm}$ ) rapidly growing colonies appeared, corresponding to approximately $3 \times 10^{5}$ $\mathrm{CFU} \mathrm{ml} \mathrm{m}^{-1}$ in the enrichment culture. Twelve such colonies were microscopically examined; they consisted exclusively of vibrio-shaped cells. Pure cultures obtained from this colony type (three strains studied) were desulfoviridin positive and not able to grow on crude oil, toluene, benzoate, butyrate, or acetate. Good growth occurred in 1 week on lactate, malate, ethanol, and $\mathrm{H}_{2}-\mathrm{CO}_{2}(80: 20$ [vol/vol], with $0.5 \mathrm{mM}$ acetate as a carbon source for cell synthesis). The cultures formed $5.3 \mathrm{mM}$ sulfide and $9.3 \mathrm{mM}$ acetate when consuming $10.9 \mathrm{mM}$ L-lactate, indicating incomplete oxidation (theoretical molar sulfide-to-lactate ratio, 1/2). These properties are characteristic of Desulfovibrio species. After a prolonged total incubation time of 3 to 4 weeks, smaller (diameter, approximately $0.2 \mathrm{~mm}$ ) colonies appeared in high numbers, corresponding to approx- imately $6 \times 10^{6} \mathrm{CFU} \mathrm{ml}^{-1}$ in the enrichment culture. Again, 12 colonies of this type were microscopically examined; they contained exclusively oval to rod-shaped cells. Pure cultures obtained from this colony type (four strains studied) were desulfoviridin negative and were able to grow slowly on lactate, butyrate, toluene, and crude oil. They formed $11.5 \mathrm{mM}$ sulfide when consuming $7.3 \mathrm{mM}$ L-lactate, indicating complete oxidation (theoretical molar sulfide-to-lactate ratio, 3/2); in agreement with this, acetate formation was not detectable.

On any substrate including crude oil, the numbers of CFU were always significantly lower than the total cell density of $5 \times$ $10^{7}$ cells per ml, as determined by means of a counting chamber. Assuming that the utilizable substrates, viz., the alkylbenzenes, diffuse from the oil into the agar, in analogy to cultures with defined carrier phases (46), it must be concluded that only a portion of the cells in the enrichment culture formed colonies in the agar.

Probe design and whole-cell hybridization. Consumption of alkylbenzenes from oil (Fig. 1) and cell counts suggest that sulfate-reducing bacteria with the ability to degrade aromatic compounds were the dominant metabolic types in the enrichment culture. So far, all known sulfate-reducing bacteria degrading aromatic compounds have the capacity for complete oxidation of organic substrates $(11,46,72)$. On the basis of $16 \mathrm{~S}$ rRNA sequences, all non-spore-forming, completely oxidizing, sulfate-reducing bacteria belong to a cluster within the delta subdivision of the Proteobacteria; the cluster was tentatively termed Desulfobacteriaceae and opposed to Desulfovibrionaceae $(20,72)$. Therefore, we expected dominance of complete oxidizers and hence of members of the Desulfobacteriaceae in the enrichment culture. To verify this assumption, several described probes labeled with fluorescent dyes were tested against whole cells in hybridization assays.

A probe termed 804 which specifically hybridized with extracted DNA from several members of the Desulfobacteriaceae (21) did not yield a hybridization signal with whole cells of selected members of this family (Desulfobacter latus, Desulfobacter postgatei, Desulfobacterium autotrophicum, Desulfobulbus propionicus, and Desulfococcus multivorans) and the enrichment culture. In agreement with other reports $(3,50)$, probe SRB385 hybridized specifically with Desulfovibrio, Desulfomicrobium, and Desulfobulbus species, but not with complete oxidizers such as Desulfobacter, Desulfobacterium, Desulfobacula, Desulfococcus, and Desulfonema species (Table 1). As expected, this probe yielded distinctive hybridization signals only with a small portion of the cells in the enrichment culture ( $<5 \%$; Fig. 2F). Sequence comparison between probe SRB385 and the target site on the 16S rRNA of most members of the Desulfobacteriaceae (Table 1) revealed a single base mismatch at position 396 (E. coli numbering). To achieve a complete match, cytosine at position 396 in probe SRB385 was substituted with thymine, yielding a probe which we termed SRB385Db. In contrast to probe SRB385, the modified probe, SRB385Db, hybridized with all tested members of the Desulfobacteriaceae, except for Desulfobulbus species, but not with Desulfovibrio species as the main representatives of the Desulfovibrionaceae. In the enrichment culture, more than $95 \%$ of the cells yielded a distinctive hybridization signal with probe SRB385Db (Fig. 2E). The signal intensity was lower than that in the case of the tested pure cultures, as can be expected for slowly growing bacteria such as those in the enrichment culture (5). Nevertheless, measurement of mean pixel intensities (7) clearly demonstrated the specificity of the hybridization in comparison with those of the other probes applied (Table 2). In control experiments, the universal bacterial (eubacterial) probe EUB338 hybridized with all reference strains and cells 
TABLE 1. Target regions of $16 \mathrm{~S}$ rRNA from various sulfate-reducing and other bacteria and results of whole-cell oligonucleotide probing

\begin{tabular}{|c|c|c|c|c|c|c|c|c|c|}
\hline \multirow{2}{*}{ Bacterial species ${ }^{a}$} & \multirow{2}{*}{ Oxidation $^{b}$} & \multirow{2}{*}{\multicolumn{3}{|c|}{$\begin{array}{l}\text { Target sequence on } \\
\text { the } 16 \mathrm{~S} \text { rRNA }^{c}\end{array}$}} & \multirow{2}{*}{$\begin{array}{l}\text { Refer- } \\
\text { ence }^{d}\end{array}$} & \multicolumn{4}{|c|}{ Fluorescence signal of probe $e^{e}$} \\
\hline & & & & & & SRB385 & SRB385Db & EUB338 & ANT \\
\hline \multicolumn{10}{|l|}{ Desulfovibrionaceae } \\
\hline Desulfovibrio africanus (DSM 2603) & I & $5^{\prime}-\mathrm{CCUGAC}$ & GCAGCGACGC & CG-3' & 20 & & & & \\
\hline Desulfovibrio desulfuricans (DSM 6949) & I & $5^{\prime}-\mathrm{CCUGAC}$ & GCAGCGACGC & CG-3' & 44 & + & - & + & - \\
\hline Desulfovibrio gigas (DSM 1382) & I & $5^{\prime}$-CCUNAC & GCAGCGACGC & CG-3' & 19 & + & - & + & - \\
\hline Desulfovibrio longus (DSM 6739) & NR & $5^{\prime}$-NNNNAC & GCAGCGACGC & CG-3' & 32 & & & & \\
\hline Desulfovibrio salexigens (DSM 2638) & I & $5^{\prime}-\mathrm{CCUGAC}$ & GCAGCGACGC & $\mathrm{CA}-3^{\prime}$ & 19 & + & - & + & - \\
\hline Desulfovibrio vulgaris (DSM 644) & I & $5^{\prime}$-CCUNAC & GCAGCGACGC & CG-3' & 19 & + & - & + & - \\
\hline Desulfovibrio sp. strain El Agheila (DSM 1926) & NR & $5^{\prime}-\mathrm{CCCNAC}$ & GCAGCGACGC & CU-3' & 20 & & & & \\
\hline Desulfovibrio sp. strain Norway 4 (DSM 1741) & NR & $5^{\prime}-\mathrm{CCUGAC}$ & GCAGCNACGC & CG-3' & 20 & + & - & + & - \\
\hline \multicolumn{10}{|l|}{ Desulfobacteriaceae } \\
\hline \multicolumn{10}{|l|}{ Sulfate reducing } \\
\hline Desulfoarculus baarsii (DSM 2075)g & $\mathrm{C}$ & $5^{\prime}-\mathrm{CCUGAC}$ & GCAGCCAUGC & CG-3' & 19 & & & & \\
\hline Desulfobacter curvatus (DSM 3379) & $\mathrm{C}$ & $5^{\prime}-\mathrm{CCUGAC}$ & GCAGCGACGC & CG-3' & 19 & & & & \\
\hline Desulfobacter hydrogenophilus (DSM 3380) & $\mathrm{C}$ & $5^{\prime}-\mathrm{CCUGAC}$ & GCAGCAACGC & CG-3' & 19 & & & & \\
\hline Desulfobacter latus (DSM 3381) & $\mathrm{C}$ & $5^{\prime}-\mathrm{CCNNAC}$ & GCAGCAAUGC & CG-3' & 19 & - & + & + & - \\
\hline Desulfobacter postgatei (DSM 2034) & $\mathrm{C}$ & $5^{\prime}-\mathrm{CCUGAC}$ & GCAGCAACGC & CG-3' & RDP & - & + & + & - \\
\hline Desulfobacter sp. strain 4ac11 (DSM 2057) & $\mathrm{C}$ & $5^{\prime}-\mathrm{CCUGAC}$ & GCAGCGACGC & CG-3' & 19 & & & & \\
\hline Desulfobacterium autotrophicum (DSM 3382) & $\mathrm{C}$ & $5^{\prime}-$ CCUNAC & GCAGCAACGC & CG-3' & 19 & - & + & + & - \\
\hline Desulfobacterium niacini (DSM 2650) & $\mathrm{C}$ & $5^{\prime}-\mathrm{CCUNAC}$ & GCAGCAACGC & NG-3' & 19 & & & & \\
\hline Desulfobacterium vacuolatum (DSM 3385) & $\mathrm{C}$ & $5^{\prime}$-CCUGAC & GCAGCAACGC & CG-3' & 19 & - & + & + & - \\
\hline Desulfobacula toluolica (DSM 7467) & $\mathrm{C}^{i}$ & $5^{\prime}-\mathrm{CCUGAC}$ & GCAGCAACGC & CG-3' & 46 & - & + & + & - \\
\hline Desulfobotulus sapovorans (DSM 2055) ${ }^{j}$ & I & $5^{\prime}-\mathrm{CCUGAC}$ & GCAGCAACGC & CG-3' & 19 & - & + & + & - \\
\hline Desulfobulbus propionicus (DSM 2032) & I & $5^{\prime}-\mathrm{CCNNAC}$ & GCAGCGACGC & NG-3' & 19 & + & - & + & - \\
\hline Desulfobulbus sp. strain 3pr10 (DSM 2058) & I & $5^{\prime}$-CCUNAC & GCAGCGACGC & CG-3' & 19 & & & & \\
\hline Desulfococcus multivorans (DSM 2059) & $\mathrm{C}$ & $5^{\prime}$-CNUNAC & GCAGCAACGC & CG-3' & 19 & - & + & + & - \\
\hline Desulfomonile tiedjei (ATCC 49306) & NR & $5^{\prime}$-UCUGAC & GCAGCAACGC & CG-3' & 22 & & & & \\
\hline Desulfonema limicola (DSM 2076) & $\mathrm{C}$ & $5^{\prime}$-CCUGAC & GCAGCAACGC & CG-3' & 25 & - & + & + & - \\
\hline Desulfonema magnum (DSM 2077) & $\mathrm{C}$ & $5^{\prime}-\mathrm{CCUGAC}$ & GCAGCAACGC & CG-3' & 25 & - & + & + & - \\
\hline Desulfosarcina variabilis (DSM 2060) & $\mathrm{C}$ & $5^{\prime}-\mathrm{CCUGAC}$ & GCAGCAACGC & CG-3' & RDP & & & & \\
\hline Strain Hxd3 (DSM 6200) & $\mathrm{C}^{k}$ & $5^{\prime}-$ CCUGAC & GCAGCAACGC & CG-3' & 2 & & & & \\
\hline \multicolumn{10}{|l|}{ Nonsulfate reducing } \\
\hline Desulfuromonas acetoxidans (DSM 684) & $\mathrm{C}^{l}$ & $5^{\prime}-\mathrm{CCUGAC}$ & GCAGCAACGC & CG-3' & RDP & - & + & + & - \\
\hline Myxococcus xanthus (DSM 435) & $\mathrm{C}^{m}$ & $5^{\prime}$-CCUGAC & GCAGCAACGC & CG-3' & 44 & - & + & + & - \\
\hline Pelobacter acetylenicus (DSM 3246) & $\mathrm{I}^{n}$ & $5^{\prime}-\mathrm{CCUGAC}$ & GCAGCAACGC & CG-3' & 24 & - & + & + & - \\
\hline \multicolumn{10}{|l|}{ Gram positive, spore forming } \\
\hline Desulfotomaculum orientis (DSM 765) & I & $5^{\prime}-$ GGCGAC & GAUCAGUAGC & CG-3' & 19 & - & - & + & - \\
\hline \multicolumn{10}{|l|}{ Other bacteria } \\
\hline Bacillus subtilis (DSM 10) & & $5^{\prime}$-UCUGAC & GGAGCAACGC & CG-3' & 36 & - & - & + & - \\
\hline Beggiatoa alba (DSM 1416) & & $5^{\prime}-\mathrm{CCUGAU}$ & CCAGCAAUGC & CG-3' & 63 & - & - & + & - \\
\hline Comamonas testosteroni (DSM 50244) ${ }^{\circ}$ & & $5^{\prime}-\mathrm{CCUGAU}$ & CCAGCAAUGC & CG-3' & 74 & - & - & + & - \\
\hline Corynebacterium variabilis (DSM 20132) & & $5^{\prime}-\mathrm{CCUGAU}$ & GCAGCGACGC & CG-3' & 15 & - & - & + & - \\
\hline Escherichia coli $\mathrm{K}-12$ (DSM 498) & & $5^{\prime}-\mathrm{CCUGAU}$ & GCAGCCAUGC & CG-3' & 61 & - & - & + & - \\
\hline Micrococcus luteus (ATCC 381) & & $5^{\prime}$-CCUNAU & GCAGCGACGC & CG-3' & RDP & & & & \\
\hline Nocardioides simplex (DSM 20130) & & $5^{\prime}-\mathrm{CCUGAU}$ & CCAGCAACGC & CG-3' & RDP & - & - & + & - \\
\hline Rhodospirillum rubrum (DSM 467) & & $5^{\prime}-\mathrm{CCUGAC}$ & GCAGCCAUGC & CG-3' & 31 & - & - & + & - \\
\hline \multicolumn{10}{|l|}{ Other organisms } \\
\hline Halobacterium halobium (DSM 670) & & $5^{\prime}$-UGCGAU & AAGGGGACUC & CG-3' & 34 & - & - & - & - \\
\hline Saccharomyces cerevisiae (DSM 70449) & & $5^{\prime}$-GGGAGG & UAGUGACAAU & $\mathrm{AA}-3^{\prime}$ & 57 & - & - & - & - \\
\hline Probe SRB385 & & $3^{\prime}-$ GGACTG & CGTCGCTGCG & GC- $5^{\prime}$ & 3 & & & & \\
\hline Target & & $5^{\prime}-\mathrm{CCUGAC}$ & GCAGCGACGC & CG-3' & & & & & \\
\hline Probe SRB385Db & & $3^{\prime}-$ GGACTG & CGTCGTTGCG & GC-5' & & & & & \\
\hline Target & & $5^{\prime}-\mathrm{CCUGAC}$ & GCAGCAACGC & CG-3' & & & & & \\
\hline
\end{tabular}

${ }^{a}$ Collection numbers are in parentheses.

${ }^{b}$ Oxidation of organic substrates. C, complete; I, incomplete; NR, not reported. If not noted otherwise, data are taken from reference 72.

${ }^{c}$ Target sequences are complementary to positions 402 to 385 on the 16S rRNA (E. coli numbering). Sequence data are from the ribosomal RNA data base project

(33) and from the European Bioinformatics database (23).

${ }^{d}$ References indicate original publication of $16 \mathrm{~S}$ rRNA sequence and phylogenetic affiliation. RDP, available only from the ribosomal data base project (33).

${ }^{e}$ For descriptions of probes, see Materials and Methods.

${ }^{f}$ Future reclassification as Desulfomicrobium baculatum appears appropriate (72).

${ }^{g}$ Formerly described as Desulfovibrio baarsii (72).

${ }^{h}$ Formerly described as Desulfococcus niacini (72).

${ }^{i}$ Reference 46.

${ }^{j}$ Formerly described as Desulfovibrio sapovorans (72).

${ }^{k}$ Reference 1 .

${ }^{l}$ Reference 73.

${ }^{m}$ Aerobic bacteria with terminal oxidation (52).

${ }^{n}$ Reference 59

${ }^{o}$ Previously named Pseudomonas testosteroni (74). 


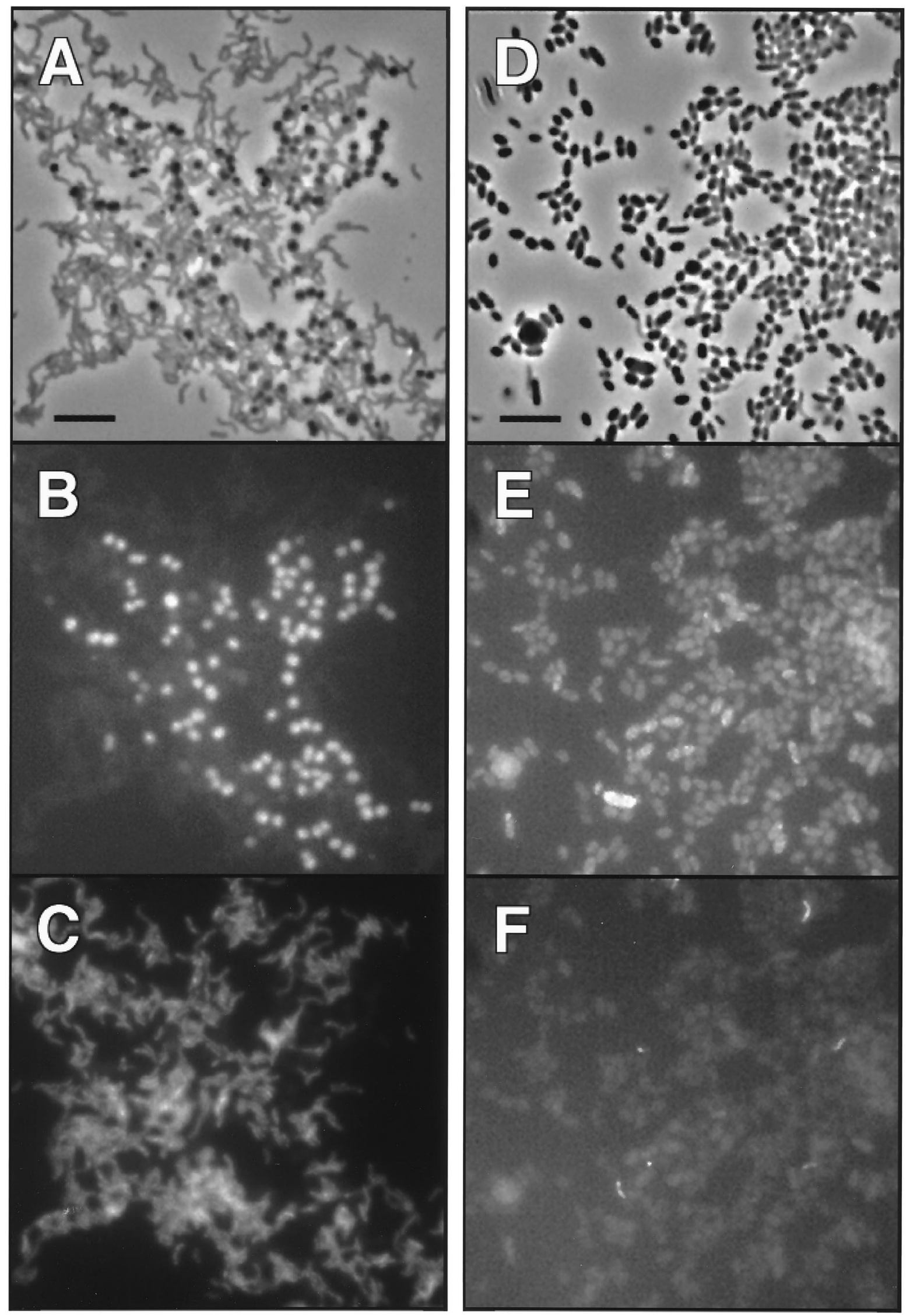


FIG. 2. Differentiation between Desulfobacteriaceae and Desulfovibrionaceae by whole-cell hybridization of reference organisms and the oil-utilizing sulfate-reducing enrichment culture. Whole-cell hybridization was carried out with the fluorescein-5-isothiocyanate-labeled probe SRB385Db (green fluorescence) and the rhodaminelabeled probe SRB385 (red fluorescence). Left panels are microscopic images of a mixture of pure cultures of the completely-oxidizing Desulfococcus multivorans (coccoid shape) and the incompletely oxidizing Desulfovibrio desulfuricans (vibrioid shape); right panels are microscopic images of the oil-utilizing enrichment culture. (A and D) Phase-contrast photomicrographs; (B and E) digital images after hybridization with probe SRB385Db and excitation at 489 nm; (C and F) digital images after hybridization with probe SRB385 and excitation at $541 \mathrm{~nm}$. Bars, $10 \mu \mathrm{m}$.

of the enrichment culture. The antisense probe ANT yielded a much weaker signal with the reference strains and the enrichment culture. In conclusion, probes SRB385 and SRB385Db allowed a differentiation between members of the Desulfovibrionaceae (incomplete oxidizers) and Desulfobacteriaceae (mostly complete oxidizers) in defined cultures (Fig. 2A to C) and the enrichment culture of sulfate-reducing bacteria (Fig. $2 \mathrm{D}$ to F).

\section{DISCUSSION}

The presently studied enrichment culture with crude oil as the only source of organic substrates may be regarded as a laboratory model of the anaerobic microbial community that grows in moderately warm oil reservoirs, wells, tanks, and pipelines on indigenous substrates. The main difference between our laboratory culture and the in situ conditions (outside in the oil field) lies in the ion concentrations in the enrichment culture being constantly the same as those in seawater and in the growth conditions being optimized by the addition of ammonium, phosphate, vitamins, and high-sulfate concentrations to achieve appropriate growth times and cell densities for the analytical experiments. Even if under the presumably nonoptimal growth conditions in oil reservoirs and production plants the sulfate-reducing bacteria probably exhibit slower and poorer growth than in the enrichment culture, a utilization of alkylbenzenes from crude oil as in the model culture should in principle be possible also under in situ conditions. This assumption is supported by other studies showing selective depletion of alkylbenzenes in incubation experiments with nondegraded oils and sulfate-reducing bacteria from reservoir waters, as well as in oils from biodegraded reservoirs (16). Therefore, it may be concluded that alkylbenzenes as an important class of oil constituents belong to the major indigenous electron donors for sulfate reduction in moderately warm oil reservoirs and production plants (viz., under mesophilic conditions), as long as no further potential electron donors are provided; these may originate from added biodegradable chemicals (17) or from partial hydrocarbon oxidation by aerobic bacteria upon access of air $(12,39)$. Actually, toluene and xylenes together may account for as much as $3 \%$ of the oil constituents (64). Other quantitatively significant indigenous electron donors might be saturated hydrocarbons, as shown with a moderately thermophilic sulfate-reducing bacterium

TABLE 2. Relative mean pixel intensities of hybridization signals obtained with cells from the oil-utilizing enrichment culture

\begin{tabular}{lcc}
\hline \multicolumn{1}{c}{ Probe } & $\begin{array}{c}\text { Mean pixel } \\
\text { intensity }^{a}\end{array}$ & $\begin{array}{c}\text { Standard } \\
\text { deviation }\end{array}$ \\
\hline SRB385Db & 83.8 & 6.2 \\
SRB385 & 19.3 & 1.5 \\
EUB338 & 69.1 & 1.7 \\
ANT & 23.6 & 2.9 \\
\hline
\end{tabular}

${ }^{a}$ Measured by using a confocal laser-scanning microscope (LSM410; Zeiss). Five microscopical sections were analyzed to determine the fluorescence intensity of cells with each probe. The size of one section was $7,300 \mu \mathrm{m}^{2}$; the number of cells per section was $\geq 800$. that grew by utilization of alkanes from crude oil (58). The possible role of mesophilic alkane-utilizing sulfate-reducing bacteria such as strain Hxd3 (1) in sulfide production has not been studied thus far in a model system. Extremely thermophilic sulfate-reducing Archaea that were detected in oil fields $(9,28,62)$ have not been shown to utilize hydrocarbons.

The assumption of an anaerobic utilization of alkylbenzenes by sulfate-reducing bacteria in oil fields has to be reconciled with the observation that alkylbenzenes are still present in many oils. The preservation of anaerobically degradable constituents in oils over geological time in our opinion has several explanations. First, at many sites in the reservoir sulfate may have become the limiting factor for anaerobic oxidation processes, because of bacterial sulfate reduction during early diagenesis and oil maturation (40). Indeed, in many production waters, sulfate concentrations of less than $1 \mathrm{mM}$ have been measured $(8,13,41)$. Second, oil in reservoirs is trapped in the pores of rocks (64), which may impede diffusion of substrates and their accessibility by bacteria. Only during the process of oil extraction by water injection may conditions for bacterial growth become favorable by mixing processes, formation of emulsions, and new contact areas between oil and water. Third, sulfate-reducing bacteria that were formerly buried with the ancient sediments may have died off in the reservoirs because of unfavorable conditions (extreme temperature and salinity) at the deep sites of catagenesis and because of sulfate depletion. Only during secondary oil recovery are new bacteria introduced with the injected water. Upon cooling and dilution, the temperature and salinity, respectively, may become favorable for a variety of bacteria wider than that which could have developed before. If seawater is injected, high concentrations of the formerly depleted electron acceptor, sulfate, are also provided. The increase in sulfide production in oil field waters after the onset of operations may reflect the gradual spreading and growth of sulfate-reducing bacteria $(17,62)$. On the other hand, there are also assumptions that sulfate-reducing bacteria as well as other microorganisms in oil fields were deposited with the original sediments and survived for millions of years $(28,41,53)$. In this case, the question would remain of how cells remained viable over such long periods. Survival appears unlikely in niches which are closed systems, viz., in which substrates are depleted after a while. A prerequisite for survival would be a minimal but more or less continuous supply of growth substrates to sustain viability over geological time, e.g., by slow hydrodynamic migration processes.

The high number of colonies obtained with toluene and benzoate confirmed that the ability to utilize aromatic compounds is a dominant physiological characteristic among the enriched cells. So far, sulfate-reducing bacteria in oil fields have often been counted and isolated with lactate $(13,37,39$, $42,54)$, a component of standard media, which is particularly useful for rapid detection of Desulfovibrio species. Desulfovibrio species are effective scavengers of hydrogen (70); they may become abundant in oil fields if hydrogen is available, for instance from corroding or cathodically protected steel surfaces $(27,71)$ or from fermentative degradation of xanthan gum which is used in enhanced oil recovery (17). Cell counting and whole-cell probing in the oil-utilizing enrichment culture 
revealed only a low percentage of Desulfovibrio species. This finding is in agreement with the experience that Desulfovibrio species are nutritionally relatively restricted and have never been reported to utilize aromatic compounds (72). In the presently studied enrichment culture, the Desulfovibrio species may have grown with low concentrations of organic compounds excreted by other cells or liberated upon cell lysis. However, Desulfovibrio species were not the only sulfate reducers that formed distinctive colonies in agar with lactate. Prolonged incubation of the agar tubes revealed high numbers of slowly growing, completely oxidizing sulfate-reducing bacteria able to grow on toluene and oil. Hence, even though lactate is not utilized by all completely oxidizing, sulfate-reducing bacteria $(46,72)$, long incubation of counting series with this substrate may allow detection of some of the species that utilize aromatic compounds in situ.

The newly applied probe SRB385Db allowed group-specific whole-cell detection for the first time of members of the $D e$ sulfobacteriaceae, a branch which besides a few incomplete oxidizers encompasses all completely oxidizing gram-negative, mesophilic sulfate-reducing bacteria. As expected from the target sequence, the probe also yielded a signal with the sulfur reducer $D$. acetoxidans, the fermentative bacterium $P$. acetylenicus, and the aerobe Myxococcus xanthus, which are all members of the delta subdivision of the Proteobacteria. Moreover, according to a search in the ribosomal data base (33), the probe would theoretically also react with Bdellovibrio species of the delta subdivision and with 8 Campylobacter species or strains, 3 Chlorobium species, 1 Bacteroides species, 2 Leptospira species, and 23 Clostridium species. The original probe, SRB385, would react with many actinomycetes. However, under the anoxic conditions in the oil-utilizing enrichment culture, which did not contain fermentable compounds, none of these non-sulfate-reducing bacteria is expected. Indeed, growth, sulfide production and anaerobic alkylbenzene utilization by the enriched bacterial population were strictly sulfate dependent (58).

For monitoring and investigation of sulfate-reducing bacteria in oil fields, alkylbenzene-degrading and other completely oxidizing species, viz., members of the Desulfobacteriaceae, will have to be considered in the future. However, for routine investigations in oil fields, the use of counting series with appropriate media and substrates appears presently easier to achieve than whole-cell hybridization with oligonucleotide probes. Even though counting series require incubation times of a few weeks, the costs for the technical expenditures are less than those for whole-cell hybridization. Recognition of potentially alkylbenzene-utilizing cells via the hybridization signal requires at least an epifluorescence microscope. Furthermore, conditions in oil wells, pipelines, and oil tanks are less defined than those in the presently studied, strictly anaerobic enrichment culture. Under incomplete exclusion of air and upon addition of chemicals such as xanthan gum to injection waters, aerobic as well as anaerobic fermentative bacteria are likely to develop and yield additional signals with the fluorescently labeled probes. In conclusion, at the present time 16S rRNAbased whole-cell hybridization appears practically useful in a selected number of scientific case studies rather than in routine monitoring of sulfate-reducing bacteria in oil fields.

\section{ACKNOWLEDGMENTS}

We thank Jürgen Fischer for providing oil samples; Werner Laumer, Angelika Ropertz, and Helmut Willsch for helpful assistance during the oil analysis; Bernhard Assmus for measurements with the confocal laser scanning microscope; Niels Birger Ramsing for his help with the image analysis system; Andreas Teske for helping with the sequence databases; and Gerda Harms for technical assistance.

This work was supported by the Max-Planck-Gesellschaft, the Deutsche Forschungsgemeinschaft, and the Fonds der Chemischen Industrie.

\section{REFERENCES}

1. Aeckersberg, F., F. Bak, and F. Widdel. 1991. Anaerobic oxidation of saturated hydrocarbons to $\mathrm{CO}_{2}$ by a new type of sulfate-reducing bacterium. Arch. Microbiol. 156:5-14.

2. Aeckersberg, F., P. Rueter, W. Ludwig, and F. Widdel. Unpublished data.

3. Amann, R. I., B. J. Binder, R. J. Olson, S. W. Chisholm, R. Devereux, and D. A. Stahl. 1990. Combination of 16S rRNA-targeted oligonucleotide probes with flow cytometry for analyzing mixed microbial populations. Appl. Environ. Microbiol. 56:1919-1925.

4. Amann, R. I., L. Krumholz, and D. A. Stahl. 1990. Fluorescent oligonucleotide probing of whole cells for determinative, phylogenetic, and environmental studies in microbiology. J. Bacteriol. 172:762-770.

5. Amann, R. I., W. Ludwig, and K.-H. Schleifer. 1995. Phylogenetic identification and in situ detection of individual microbial cells without cultivation. Microbiol. Rev. 59:143-169.

6. American Type Culture Collection. 1992. Catalogue of bacteria and bacteriophages, 18th ed. American Type Culture Collection, Rockville, Md.

7. Assmus, B., P. Hutzler, G. Kirchhof, R. Amann, J. R. Lawrence, and A Hartmann. 1995. In situ localization of Azospirillum brasilense in the rhizosphere of wheat with fluorescently labeled, rRNA-targeted oligonucleotide probes and scanning confocal laser microscopy. Appl. Environ. Microbiol. 61:1013-1019.

8. Barth, T. 1991. Organic acids and inorganic ions in waters from petroleum reservoirs, Norwegian continental shelf: a multivariate statistical analysis and comparison with American reservoir formation waters. Appl. Geochem. 6:1-15.

9. Beeder, J., R. K. Nilsen, J. T. Rosnes, T. Torsvik, and T. Lien. 1994. Archaeoglobus fulgidus isolated from hot North Sea oil field waters. Appl. Environ. Microbiol. 60:1227-1231.

10. Beeder, J., T. Torsvik, and T. Lien. 1995. Thermodesulforhabdus norvegicus gen. nov., sp. nov., a novel thermophilic sulfate-reducing bacterium from oil field water. Arch. Microbiol. 164:331-336.

11. Beller, H. R., A. M. Spormann, P. K. Sharma, J. R. Cole, and M. Reinhard. 1996. Isolation and characterization of a novel toluene-degrading, sulfatereducing bacterium. Appl. Environ. Microbiol. 62:1188-1196.

12. Belyaev, S. S., K. S. Laurinavichus, A. Y. Obraztsova, S. N. Gorlatov, and M. V. Ivanov. 1983. Microbiological processes in the critical zone of injection wells in oilfields. Microbiology 51:793-797. (English translation from Mikrobiologiya 51:997-1001, 1982.)

13. Belyaev, S. S., E. P. Rozanova, I. A. Borzenkov, I. A. Charakhch'yan, Y. M. Miller, M. Y. Sokolov, and M. V. Ivanov. 1991. Characteristics of microbiological processes in a water-flooded oilfield in the Middle Ob' region. $\mathrm{Mi}-$ crobiology 59:754-759. (English translation from Mikrobiologiya 59:10751081, 1991.)

14. Burgund, A. E., and T. Barth. 1994. Generation of short-chain organic acids from crude oil by hydrous pyrolysis. Org. Geochem. 21:943-952.

15. Collins, M. D., J. Smida, and E. Stackebrandt. 1989. Phylogenetic evidence for the transfer of Caseobacter polymorphus (Crombach) to the genus Corynebacterium. Int. J. Syst. Bacteriol. 39:7-9.

16. Connan, J., G. Lacrampe, and M. Magot. Personal communication.

17. Cord-Ruwisch, R., W. Kleinitz, and F. Widdel. 1987. Sulfate-reducing bacteria and their activities in oil production. J. Petrol. Technol. 1987 (January): 97-106.

18. Deutsche Sammlung von Mikroorganismen und Zellkulturen. 1993. Catalogue of strains, 5th ed. Deutsche Sammlung von Mikroorganismen und Zellkulturen, Braunschweig, Germany.

19. Devereux, R., M. Delaney, F. Widdel, and D. A. Stahl. 1989. Natural relationships among sulfate-reducing eubacteria. J. Bacteriol. 171:6689-6695.

20. Devereux, R., S.-H. He, C. Doyle, S. Orkland, D. A. Stahl, J. LeGall, and W. B. Whitman. 1990. Diversity and origin of Desulfovibrio species: phylogenetic definition of a family. J. Bacteriol. 172:3609-3619.

21. Devereux, R., M. D. Kane, J. Winfrey, and D. A. Stahl. 1992. Genus- and group-specific hybridization probes for determinative and environmental studies of sulfate-reducing bacteria. Syst. Appl. Microbiol. 15:601-609.

22. DeWeerd, K. A., L. Mandelco, R. S. Tanner, C. R. Woese, and J. M. Suflita 1990. Desulfomonile tiedje gen. nov. and sp. nov., a novel anaerobic, dehalogenating, sulfate-reducing bacterium. Arch. Microbiol. 154:23-30.

23. Emmert, D. B., P. J. Stoehr, G. Stoesser, and G. N. Cameron. 1994. The European Bioinformatics Institute (EBI) databases. Nucleic Acids Res. 22: 3445-3449.

24. Evers, S., M. Weizenegger, W. Ludwig, B. Schink, and K.-H. Schleifer. 1993. The phylogenetic positions of Pelobacter acetylenicus and Pelobacter propionicus. Syst. Appl. Microbiol. 16:216-218.

25. Fukui, M., G. Muyzer, A. Teske, B. Assmus, and F. Widdel. Unpublished data. 
26. Fukui, M., Y. Suwa, and Y. Urushigawa. 1996. High survival efficiency and ribosomal RNA decaying pattern of Desulfobacter latus, a highly specific acetate-utilizing organism, during starvation. FEMS Microbiol. Ecol. 19:1725 .

27. Hamilton, W. A. 1985. Sulphate-reducing bacteria and anaerobic corrosion. Annu. Rev. Microbiol. 39:195-217.

28. L'Haridon, S., A.-L. Reysenbach, P. Glénat, D. Prieur, and C. Jeanthon. 1995. Hot subterranean biosphere in a continental oil reservoir. Nature (London) 367:223-224.

29. Hartgers, W. A., J. S. Sinninghe Damsté, and J. W. de Leeuw. 1992. Identification of $\mathrm{C}_{2}-\mathrm{C}_{4}$ alkylated benzenes in flash pyrolysates of kerogens, coals and asphaltenes. J. Chromatogr. 606:211-220.

30. Herbert, B. N. 1987. Reservoir souring, p. 63-71. In E. C. Hill, J. L. Shennan, and R. J. Walkinson (ed.), Microbial problems in the offshore oil industry. John Wiley \& Sons, London.

31. Kishimoto, N., Y. Kosako, N. Wakao, T. Tano, and A. Hiraishi. 1995. Transfer of Acidiphilium facilis and Acidiphilium aminolytica to the genus Acidocella gen. nov., and emendation of the genus Acidiphilium. Syst. Appl. Microbiol. 18:85-91.

32. Magot, M., P. Caumette, J. M. Desperrier, R. Matheron, C. Dauga, F. Grimont, and L. Carreau. 1992. Desulfovibrio longus sp. nov., a sulfatereducing bacterium isolated from an oil-producing well. Int. J. Syst. Bacteriol. 42:398-403.

33. Maidak, B. L., N. Larsen, M. J. McCaughey, R. Overbeck, G. J. Olsen, K. Fogel, J. Blandy, and C. R. Woese. 1994. The ribosomal database project. Nucleic Acids Res. 22:3485-3487.

34. Mankin, A. S., V. K. Kagramanova, N. L. Teterina, P. M. Rubtsov, E. N. Belova, A. M. Kopylov, L. A. Baratova, and A. A. Bogdanov. 1985. The nucleotide sequence of the gene coding for the 16S rRNA from archaebacterium Halobacterium halobium. Gene 37:181-189.

35. Means, J. L., and N. Hubbard. 1987. Short-chain aliphatic acid anions in deep subsurface brines: a review of their origin, occurrence, properties, and importance and new data on their distribution and geochemical implications in the Palo Duro Basin, Texas. Org. Geochem. 11:177-191.

36. Moriya, S., N. Ogasawara, and H. Yoshikawa. 1985. Structure and function of the region of the replication origin of Bacillus subtilis chromosome. III. Nucleotide sequence of some 10,000 base pairs in the origin region. Nucleic Acids Res. 13:2251-2265.

37. Nazina, T. N., A. E. Ivanova, O. V. Golubeva, R. R. Ibatullin, S. S. Belyaev, and M. V. Ivanov. 1995. Occurrence of sulfate- and iron-reducing bacteria in stratal waters of the Romashkinskoe oil field. Microbiology 64:203-208. (English translation from Mikrobiologiya 64:245-251, 1995.)

38. Nazina, T. N., and E. P. Rozanova. 1978. Thermophilic sulfate-reducing bacteria from oil strata. Microbiology 47:113-118. (English translation from Mikrobiologiya 47:142-148, 1978.)

39. Nazina, T. N., E. P. Rozanova, and S. I. Kuznetsov. 1985. Microbial oil transformation processes accompanied by methane and hydrogen sulfide formation. Geomicrobiol. J. 4:103-130.

40. Nielsen, H., J. Pilot, L. N. Grinenko, V. A. Grinenko, A. Y. Lein, J. W. Smith, and R. G. Pankina. 1991. Lithospheric source of sulphur. Scope 43:65-132.

41. Nilsen, R. K., J. Beeder, T. Thorstenson, and T. Torsvik. 1996. Distribution of thermophilic marine sulfate reducers in North Sea oil field waters and oil reservoirs. Appl. Environ. Microbiol. 62:1793-1798.

42. Odom, J. M. 1993. Industrial and environmental activities of sulfate-reducing bacteria, p. 189-210. In J. M. Odom and R. Singleton, Jr. (ed.), The sulfatereducing bacteria: contemporary perspectives. Springer-Verlag, New York.

43. Orr, W. L. 1974. Changes in sulfur content and isotopic ratios of sulfur during petroleum maturation-study of Big Horn Basin paleozoic oils. Am. Assoc. Pet. Geol. Bull. 58:2295-2318.

44. Oyaizu, H., and C. R. Woese. 1985. Phylogentic relationships among the sulfate respiring bacteria, myxobacteria and purple bacteria. Syst. Appl. Microbiol. 6:257-263.

45. Postgate, J. R. 1984. The sulphate-reducing bacteria. Cambridge University Press, Cambridge.

46. Rabus, R., R. Nordhaus, W. Ludwig, and F. Widdel. 1993. Complete oxidation of toluene under strictly anoxic conditions by a new sulfate-reducing bacterium. Appl. Environ. Microbiol. 59:1444-1451.

47. Rabus, R., and F. Widdel. 1995. Anaerobic degradation of ethylbenzene and other aromatic hydrocarbons by new denitrifying bacteria. Arch. Microbiol. 163: $96-103$.

48. Rabus, R., and F. Widdel. 1996. Utilization of alkylbenzenes during anaerobic growth of pure cultures of denitrifying bacteria on crude oil. Appl. Environ. Microbiol. 62:1238-1241.

49. Radke, M., H. Willsch, and D. H. Welte. 1980. Preparative hydrocarbon group type determination by automated medium pressure liquid chromatography. Anal. Chem. 52:406-411.

50. Ramsing, N. B., M. Kühl, and B. B. Jørgensen. 1993. Distribution of sulfatereducing bacteria, $\mathrm{O}_{2}$, and $\mathrm{H}_{2} \mathrm{~S}$ in photosynthetic biofilms determined by oligonucleotide probes and microelectrodes. Appl. Environ. Microbiol. 59: 3840-3849.

51. Rees, G. N., G. S. Grassia, A. J. Sheehy, P. P. Dwivedi, and B. K. C. Patel.
1995. Desulfoacinium infernum gen. nov., sp. nov., a thermophilic sulfate-reducing bacterium from a petroleum reservoir. Int. J. Syst. Bacteriol. 45:85-89.

52. Reichenbach, H., and M. Dworkin. 1993. The Myxobacteria, p. 3416-3487. In A. Balows, H. G. Trüper, M. Dworkin, W. Harder, and K.-H. Schleifer (ed.), The prokaryotes, 2nd ed., vol IV. Springer-Verlag, New York.

53. Rosnes, J. T., T. Torsvik, and T. Lien. 1991. Spore-forming thermophilic sulfate-reducing bacteria isolated from North Sea oil field waters. Appl Environ. Microbiol. 57:2302-2307.

54. Rozanova, E. P., A. S. Galushko, and A. E. Ivanova. 1991. Distribution of sulfate-reducing bacteria utilizing lactate and fatty acids in anaerobic ecotopes of flooded petroleum reservoirs. Microbiology 60:251-256. (English translation from Mikrobiologiya 60:360-367, 1990.)

55. Rozanova, E. P., T. N. Nazina, and A. S. Galushko. 1989. Isolation of a new genus of sulfate-reducing bacteria and description of a new species of this genus, Desulfomicrobium apsheronum gen. nov., sp. nov. Microbiology 57: 514-520. (English translation from Mikrobiologiya 57:624-641, 1988.)

56. Rozanova, E. P., and T. A. Pivovarova. 1988. Reclassification of Desulfovibrio thermophilus (Rozanova, Khudyakova, 1974). Microbiology 57:85-89. (English translation from Mikrobiologiya 57:102-106, 1988.)

57. Rubtsov, P. M., M. M. Musakhanov, V. M. Zakharyev, A. S. Krayev, K. G. Skryabin, and A. A. Bayev. 1980. The structure of the yeast ribosomal RNA genes. I. The complete nucleotide sequence of the $18 \mathrm{~S}$ ribosomal RNA gene from Saccharomyces cerevisiae. Nucleic Acids Res. 8:5779-5794.

58. Rueter, P., R. Rabus, H. Wilkes, F. Aeckersberg, F. A. Rainey, and H. W. Jannasch. 1994. Anaerobic oxidation of hydrocarbons in crude oil by new types of sulfate-reducing bacteria. Nature (London) 372:455-458.

59. Schink, B. 1993. The genus Pelobacter, p. 3393-3399. In A. Balows, H. G Trüper, M. Dworkin, W. Harder, and K.-H. Schleifer (ed.), The prokaryotes, 2nd ed., vol IV. Springer-Verlag, New York.

60. Scott, P. J. B., and M. Davies. 1993. Souring of new Irian Jaya wells traced to indigenous bacteria. Oil \& Gas J. 1993 (June):47-51.

61. Shen, W.-F., C. L. Squires, and C. L. Squires. 1982. Nucleotide sequence of the rrnG ribosomal RNA promoter region of Escherichia coli. Nucleic Acids Res. 10:3303-3313.

62. Stetter, K. O., R. Huber, E. Blöchl, M. Kurr, R. D. Eden, M. Fielder, H. Cash, and I. Vance. 1993. Hyperthermophilic archaea are thriving in deep North Sea and Alaskan oil reservoirs. Nature (London) 365:743-745.

63. Teske, A. P., N. B. Ramsing, J. Kuever, and H. Fossing. 1996. Phylogeny of Thioploca and related filamentous sulfide-oxidizing bacteria. Syst. Appl. Microbiol. 18:517-526.

64. Tissot, B. P., and D. H. Welte. 1984. Petroleum formation and occurrence, 2nd ed. Springer-Verlag, Berlin.

65. Voordouw, G., S. M. Armstrong, M. F. Reimer, B. Fouts, A. J. Telang, Y Shen, and D. Gevertz. 1996. Characterization of 16S rRNA genes from oil field microbial communities indicates the presence of a variety of sulfatereducing, fermentative, and sulfide-oxidizing bacteria. Appl. Environ. Microbiol. 62:1623-1629.

66. Voordouw, G., V. Niviere, F. G. Ferris, P. M. Fedorak, and D. W. S. Westlake. 1990. Distribution of hydrogenase genes in Desulfovibrio spp. and their use in identification of species from the oil field environment. Appl. Environ. Microbiol. 56:3748-3754.

67. Voordouw, G., Y. Shen, C. S. Harrington, A. J. Telang, T. R. Jack, and D. W. S. Westlake. 1993. Quantitative reverse sample genome probing of microbial communities and its application to oil field production waters. Appl. Environ. Microbiol. 59:4101-4114.

68. Voordouw, G., J. K. Voordouw, T. R. Jack, J. Foght, P. M. Fedorak, and D. W. S. Westlake. 1992. Identification of distinct communities of sulfatereducing bacteria in oil fields by reverse sample genome probing. Appl. Environ. Microbiol. 58:3542-3552.

69. Voordouw, G., J. K. Voordouw, R. R. Karkhoff-Schweizer, P. M. Fedorak, and D. W. S. Westlake. 1991. Reverse sample genome probing, a new technique for identification of bacteria in environmental samples by DNA hybridization, and its application to the identification of sulfate-reducing bacteria in oil field samples. Appl. Environ. Microbiol. 57:3070-3078.

70. Widdel, F. 1988. Microbiology and ecology of sulfate-reducing bacteria, $p$ 469-585. In A. J. B. Zehnder (ed.), Biology of anaerobic microorganisms, vol. 3. Carl Hanser Verlag, Munich.

71. Widdel, F. 1992. Microbial corrosion, p. 261-318. In R. K. Finn, P. Präve, M. Schlingmann, W. Crueger, K. Esser, R. Thauer, and F. Wagner (ed.), Biotechnology focus 3. Hanser Publishers, Munich.

72. Widdel, F., and F. Bak. 1992. Gram-negative mesophilic sulfate-reducing bacteria, p. 3352-3378. In A. Balows, H. G. Trüper, M. Dworkin, W. Harder, and K.-H. Schleifer (ed.), The prokaryotes, 2nd ed. vol IV. Springer-Verlag, New York.

73. Widdel, F., and N. Pfennig. 1993. The genus Desulfuromonas and other gram-negative sulfur-reducing eubacteria, p. 3379-3392. In A. Balows, H. G. Trüper, M. Dworkin, W. Harder, and K.-H. Schleifer (ed.), The prokaryotes, 2nd ed., vol IV. Springer-Verlag, New York.

74. Yang, D., Y. Oyaizu, H. Oyaizu, G. J. Olsen, and C. R. Woese. 1985. Mitochondrial origins. Proc. Natl. Acad. Sci. USA 82:4443-4447. 